\title{
IDENTITETNE TRANSFORMACIJE V MIGRACIJSKIH PROCESIH: PRELIVAJOČA SE PRIPADNOST KANADČANKE SLOVENSKO-ITALIJANSKIH KORENIN
}

\author{
Urška STRLE
}

COBISS 1.01

\section{IZVLEČEK}

\section{Identitetne transformacije v migracijskih procesih:}

Prelivajoča se pripadnost Kanadčanke slovensko-italijanskih korenin

Članek na podlagi življenjske zgodbe Anne Urbancic, dolgoletne profesorice italijanskih študij na Univerzi Toronto, zrcali identitetne transformacije. Rekonstrukcija njene zgodbe temelji na intervjuju, v katerem osvetljuje svojo kompleksno priseljensko dediščino, in na njenih različnih premišljevanjih o svoji kulturni identiteti v Kanadi. Njene pripovedi iz zadnjih dveh desetletij kažejo na istovetenje kot stalno spreminjajoči se proces, ki v veliki meri nastaja iz notranje percepcije zunanjega sveta. Pri tem sta najpomembnejši njena humanistična miselnost in izostrena družbena senzibilnost.

KLJUČNE BESEDE: Kanada, Slovenci, migracije, identiteta, življenjska zgodba

\section{ABSTRACT \\ Identity Transformations in Migratory Processes: \\ The Fluid Belonging of a Canadian with Slovenian-Italian Roots}

The article reflects the identity transformations in the life story of Anne Urbancic, a long-term professor of Italian at the University of Toronto. The reconstruction of her story is based on an interview aimed to elucidate her complex immigrant heritage and on various publications about her cultural identity in Canada. Her accounts emerging over the last two decades demonstrate identity as a constantly evolving process, stemming a great deal from the internal perception of the outer world. In these terms, her humanistic mindset and sharpened social sensibilities turned out to be of utmost importance.

KEYWORDS: Canada, Slovenians, migration, identity, life story

Dr. zgodovine, docentka, Filozofska fakulteta Univerze v Ljubljani, Aškerčeva 2, SI-1000 Ljubljana; ursulus@yahoo.com, https://orcid.org/0000-0002-1793-0090 — Članek je nastal v okviru projekta »EIRENE«, ki ga je financiral Evropski raziskovalni svet v okviru programa Horizon 2020 in v finančni shemi ERC Advanced Grant (ERC Grant Agreement n. 742683). 


\section{UVOD}

Moje ime je Anne Urbančič in to je eno od mojih imen. Včasih sem znana kot Anica Urbančič, Anica Urbančičeva ali Anica Jernačeva, Jernačeva Anica ali Anne Urbancic, odvisno. Rojena sem bila v Kanadi kmalu potem, ko so moji starši prišli iz zmešnjave, ki je ostala po vojni. ${ }^{1}$

Dr. Anne Urbancic, Kanadčanka primorskih staršev, je dolgoletna profesorica italijanskih študij na Victoria College Univerzi v Torontu, najstarejši kanadski univerzi. ${ }^{2}$ Do leta 2015, ko je prevzela funkcijo vodje akademskih programov (Academic Program Director), je poučevala italijanščino kot tuji jezik ter italijansko kulturo in literaturo 19. in 20. stoletja. Od leta 2018 je delno upokojena, kar pomeni, da v omejenem obsegu še vedno lahko predava, hkrati pa posebna delovna pogodba od nje ne zahteva nobene administrativne udeležbe. »Ta dogovor mi je všeč, ker mi omogoča, da še naprej ostajam v stiku s študenti (v takšnem okolju res uspevam), hkrati pa mi omogoča več časa za raziskovanje. $\aleph^{3} \mathrm{~V}$ času vmesnega pedagoškega statusa ima poseben pedagoški naziv, Mary Rowell Jackman Professor of Humanities, ki velja do njene polne upokojitve. Prejela ga je »kot priznanje za zasluge in prispevek k razcvetu Univerze in njenih programov«. ${ }^{4}$

Naklonjena je interdisciplinarnim pedagoškim programom z manjšimi skupinami študentov, veliko terenskimi izleti in interaktivno zastavljenimi predavanji. Intervju v enem od spletnih univerzitetnih glasil jasno očrta njene vedoželjnost, naklonjenost kritični misli in družbeno občutljivost, obenem pa poudarja pomen empatije. »Razumeti, da obstaja drugačna perspektiva in da mi študenti dajo toliko, kot dam jaz njim. Ko jih opazujem, si mislim, ste ljudi moram pripraviti za službe, ki še ne obstajajo, in to je zahtevna naloga. Ne jih zatirati, ampak jim dati samozavest in znanje, da to zmorejo.« (Spletni vir 1)

Ob pedagoškem delu, za katerega je prejela več univerzitetnih priznanj, se posveča znanstvenim aktivnostim s področja italijanistike ${ }^{5}$, metodologiji ustne zgodovine in semiotiki. V preizkušenem tandemu z univerzitetno kolegico Giuliano Sanguinetti

1 Če ni navedeno drugače, so citati vzeti iz posnetega intervjuja. Vsi angleški prevodi so delo avtorice članka.

2 Victoria College je bil leta 1836 v čast angleški kraljici Viktoriji ustanovljen le devet let po vzpostavitvi Univerze v Torontu. Je alma mater več znanih osebnosti, med njimi so Margaret Atwood, E. J. Pratt, Donald Sutherland, Lester B. Pearson in Arnold Sifton. Še danes izkazuje visoko stopnjo priljubljenosti in rigoroznosti.

3 Po elektronski pošti, 29. 6. 2020.

4 Naziv za častno profesuro, ki ga je v čast svoji materi Mary Rowell Jackman predlagal kanadski poslovnež in filantrop Hal Jackman (1932).

5 Študija o toskanskem pisatelju (Urbancic 2014b) je nedavno izšla tudi v italijanščini (Mario Pratesi: All'ombra dei cipressi. Firence: Società Editrice fiorentina, 2018). Uredila je knjigo intervjujev z osrednjimi kanadskimi literati (Urbancic 2017) in je avtorica številnih znanstvenih člankov, objavljenih $v$ akademskih revijah v Ameriki in Evropi. $V$ zadnjem času se posveča kulturi hrane, zlasti italijanske. 
Katz se je angažirala tudi kot prevajalka treh italijanskih novel $v$ angleščino in kot avtorica uvodnih študij. Za odličen prevod knjige Angele Bianchini La ragazza in nero ji je italijanska vlada podelila Premio Nazionale per la Traduzione (Urbancic 2002).

Življenjska pripoved Anne Urbancic ni predmet mojih razmišljanj zaradi njenega - kot priča skromna skica njenega javnega delovanja - družbenega uspeha. Zanimiva je zaradi več neobičajnih, unikatnih stališč, ki ne le zrcalijo, ampak tudi osmišljajo pogoste identitetne dileme potomcev priseljencev. Anne je sebi in svoji razširjeni družini večkrat pripisovala marginalizirano pozicijo, kot $v$ Kanadi rojeni potomki para s slovensko-italijanskega obmejnega območja ${ }^{6}$ jo je določala troslojna etiketa drugorazrednosti; $v$ Kanadi kot hčer priseljencev, med italijansko skupnostjo v Kanadi kot Slovenko, med slovenko skupnostjo v Kanadi pa kot »nepravo Slovenko«, morko, v nekaj primerih celo Italijanko. Prav med temi označevalci se kljub njihovim izključevalnim tendencam preliva njena kanadska identiteta.

\section{NEKAJ METODOLOŠKIH IZHODIŠČ}

Za Anne Urbančič sem prvič slišala jeseni 2007 med načrtovanjem preučevanja kanadskih Slovencev. Inštitutski kolega dr. Marjan Drnovšek mi jo je predlagal kot osebo, ki bi mi lahko pomagala pri terenskem delu v Torontu. Prvi stik sva navezali po elektronski pošti in že $v$ teh zapisih je delovala strokovno podkovano, obenem pa velikodušno in spodbujajoče. Moj prvotni vtis o njej se do danes ni kaj dosti spremenil, okrepljen s številnimi pozitivnimi izkušnjami se je kvečjemu oplemenitil.

Moj naklonjeni in s plodnim sodelovanjem podčrtani odnos do prof. Anne Urbancic nemara deluje pristransko in zato manj primeren za analizo. Vsak zapis življenjske zgodbe, ki temelji na ustnem viru, je subjektiven. Ustni vir premore specifično

6 Gre za prostor, ki nima jasno definiranih meja, zaznamuje ga preplet italijanske in slovenske kulture. Ta se je kazal (in se še kaže) zlasti v jezikovnih praksah, rabi toponimov in prehrani. Kulturni naboj je močno določalo večkratno premikanje političnih meja, ki je zajemalo obdobje med letoma 1866 (dunajska mirovna pogodba) in 1954 (londonski memorandum, ki ga je Italija formalno potrdila šele leta 1975 s podpisom osimskih sporazumov), predvsem pa rapalska razmejitev.

7 Anne Urbancic $v$ intervjuju jasno pove, da je v povojnih letih del slovenske skupnosti v Torontu diskriminiral prišleke primorskega rodu. Zakaj je prihajalo do tovrstnih razprtij, $v$ tej fazi ni mogoče definitivno zatrditi, zato poudarjam le hipotezo, ki bi potrebovala empirično podprto argumentacijo. Društveno življenje v Kanadi je bilo po vojni sicer raznovrstno, vendar ni izkazovalo le ideoloških in interesnih (šport, šah, lov) razlik, ampak tudi regionalne specifike (prekmurska, belokranjska, primorska društva), pri čemer so imela najmočnejšo pozicijo osrednjeslovenska društva. Močne regionalne identitete, odraz neenakomernega zgodovinskega razvoja slovenskega prostora, so pustile sledi ne le v Sloveniji (spomnimo samo na pogosto odklonilen odnos do (slovenskih) primorskih beguncev na Slovenskem med veliko vojno in po njej), ampak so se odražale tudi v diasporični realnosti. Ustanavljanje društev na podlagi regionalnih provenienc je treba razumeti v kontekstu specifičnih kulturnih potez (nanašajočih se na prehrano, ljudsko izročilo, jezik, kolektivni spomin ipd.), ki so bile težje združljive s primerljivimi iz osrednje Slovenije. 
kredibilnost, njegova povednost je bolj kot na dejstva vezana na onirično in simbolizem, domišljijo in strasti. Kot je zapisal Alessandro Portelli, se celo faktično napačne, netočne izjave lahko izkažejo za pravilne, povedne v psihološkem smislu (Portelli 1991: 51). Obenem je neobjektivnost lastnost, ki jo s kritičnim pretresom nastanka in namena lahko pripišemo vsakemu pisnemu viru. Ker raziskovalci (ustne) zgodovine težimo k nikoli povsem dosegljivi objektivnosti, z metodološkega vidika osvetlitev lastnih subjektivnih silnic $v$ odnosu do študijskega primera razumem kot enega od ključnih korakov k njegovi objektivizaciji.

$Z$ razkrivanjem kakovostnih vezi $z$ Anne ${ }^{8}$ poudarjam tudi obrise najine intersubjektivnosti, zgrajene na medosebnem zaupanju in vzajemni naklonjenosti, ki so izhodišče za oblikovanje dragocenih narativnih drobcev. Ti niso le posledica spominjanja, ampak tudi čustvovanja, asociacijskih impulzov in idejnih utemeljitev, ki nastajajo ob na videz linearnem pripovedovanju o preteklosti. ${ }^{9}$ Omogočajo kompleksnejši vpogled v sogovornikove dogajalne poudarke in čustvene odzive nanje, nekaj »najbolj neizprosno subjektivnega«, obenem pa »implicirajo odnose človeka do človeka, kolektivne odnose«, kot v eseju Kako rekonstruirati afektirano življenje nekoč? pronicljivo ugotavlja Lucian Febvre (2015: 122-123).

Annina zgodba ponuja živahen razmislek o specifičnih identitetnih nastavkih, integrativnih realnostih ter spremenljivem občutku pripadnosti, ki v vselej unikatnih različicah pogosto pritičejo osebam z migrantskim ozadjem (Hall 1990: 222-237). Poleg tega mi je ponudila premislek o vrednosti obrobnih pozicij, ki v sebi nosijo pozornosti vredna opazovališča. Po eni strani ji njena manj angažirana diasporična umeščenost omogoča izdaten prostor za kritično distanco. Na tem mestu poudarjam, da Annina refleksija lastnih življenjskih izkušenj poteka v luči kritično usmerjenih humanističnih osebnosti, ki so jo poklicno navdihovale in na katere se sklicuje, to so denimo Edward Said, Michel Foucault, Jacques Derrida, Vicki Galloway, Patricia Chaput, Umberto Eco, Luigi Pirandello in Patricia Hampl. Po drugi strani pa Annina pozicija vključuje intenziven insajderski vpogled, zlasti seznanjenost s kanadsko, z italijansko ter s slovensko kulturo in jeziki. Njeno pozornost slovensko-kanadski skupnosti motivira družinsko ozadje, ki obenem preudarno vključuje težavne, travmatične vidike, kar v dialoških naracijah pogosto izostane. Za njen premišljevalski položaj bi lahko rekli, da združuje etski in emski način opazovanja, kombinira teoretski in empirični pristop in je začinjen z veliko mero samoopazovanja in iz njih izvirajočih premislekov.

8 Čeprav Anne Urbancic v članku poimenujem Anne, to ni izraz omalovaževanja, prav nasprotno, je predvsem odraz medosebne bližine in spoštljive kolegialnosti.

9 Upoštevanje intersubjektivnosti je eden od temeljev razumevanja ustne zgodovine. Tovrstni premisleki terjajo uvide v medosebne dinamike spraševanca in spraševalca, njune spoznavne samorefleksije pa tudi razmerja med individualno in kolektivno (družinsko, sosedsko, narodno, regijsko, rasno, generacijsko, versko, idejno, poklicno ipd.) preteklostjo. Pomenljive razmisleke o omenjenih dinamikah, ki se zrcalijo v intervjujih, je iz Freudove psihoanalize na ustnozgodovinski teren med prvimi prinašala Luisa Passerini. Passerini (2008: 215-319) 
Podobno kot spomin se sčasoma spreminjamo tudi ljudje. Oseba, kakršna sem bila pred dvajsetimi leti, gotovo ni enaka osebi, kakršna sem danes. Prav tako danes nisem oseba, kakršna bom čez dvajset let. Mar ni zanimivo, da v podoživljanju spominov, kdo sem bila in kaj sem počela dolgo nazaj, vidim sledi sebe v sedanjosti, in da celo predpostavljam, kdo bom v prihodnosti? Ali, rečem raje, približno takšna oseba, ki sem bila in ki bom postala. In prav tu leži najpomembnejše dejstvo spomina: vedno je le približen, nikoli ni točen. Feedback ali spominjanje preteklosti in njeno kontrastno dopolnilo, feedforward ali predstavljanje prihodnosti, nikdar nista dokumentarni dejstvi, ampak zamegljena senzorična percepcija. Vselej izmuzljiva in nedokazljiva. (Urbancic 2002: 16)

Anne Urbancic je z vstopom v humanistične kroge vzpostavila niz intelektualnih orodij, ki so ji omogočila kakovosten metodološki presek med lastno izkušnjo in teoretskimi oprimki. Razmišljanja o sebi je večkrat reflektirala v znanstvenih publikacijah, katerih v nadaljevanju citirani odlomki podpirajo in dopolnjujejo vsebino najinega pogovora (Urbancic 1998; 1999; 2014a). Čeprav sva se v njeni univerzitetni pisarni na Victoria College pogovarjali v precejšnji časovni stiski, lahko pogovor ocenim kot pozornosti vredno izkušenjsko refleksijo. Po več kot osmih letih je vsebina intervjuja za Anne, kot je nedavno napisala v elektronski pošti, v ključnih potezah še vedno merodajna. ${ }^{10}$ Ker so Annini refleksivni zapisi z najino komunikacijo vred nastajali v različnih časovnih obdobjih (1998, 1999, 2012, 2014, 2020), omogočajo vpogled v razvoj njenega doživljanja svoje lastne identitete, ki se kristalizira zlasti $v$ vsebinskih poudarkih, tudi tišinah, vsebinskih odsotnostih. Nekaj vsebinskih popravkov in dopolnil sva naredili še ob avtorizaciji članka, kar je ravno tako odraz časovno pogojene spremenljivosti. ${ }^{11}$

Intervju iz leta 2012, ki je empirični temelj pričujočega prispevka, je potekal v angleščini, jeziku, v katerem po svoji presoji lahko najbolj kompetentno izraža svoje misli. Povsem suvereno bi se lahko izražala še v italijanščini in francoščini, medtem ko se v slovenščini ne čuti dovolj samozavestna. Zborne slovenščine se je v šestdesetih letih učila na sobotni slovenski šoli, njen materni jezik pa je svojska mešanica pivških in vipavskih narečij. Na pogovorni ravni slovenski jezik presenetljivo dobro obvlada, čeprav ga je pretežno govorila le $v$ ožjem krogu svoje primarne družine. Kramljali sva v pogovorni slovenščini, ki se je povsem spontano pretakala iz angleščine v slovenščino, kar je običajno med slovenskimi Kanadčani. Čeprav se v njeno slovensko izražanje umevno vrivajo angleške besede, z italijanščino obarvano narečje in slovenski arhaizmi, Anne z razumevanjem slovenščine nima zadreg. In to kljub poroki

10 Po elektronski korespondenci z avtorico, 17. 4. 2020.

11 Nekaj vsebinskih popravkov je $v$ interpretativnem delu besedila, nekaj pa tudi $v$ Anninih citatih. Nastali so iz želje po večji narativni učinkovitosti in stilistični nedvoumnosti ter izpustitvi tretjih oseb, nebistvenih za razumevanje pripovedi. $V$ narativnih delih o očetu, ki je bil med intervjujem še živ, je Anne posodobila glagolski čas iz sedanjika v preteklik. Oblikovno so dopolnila vidna v oglatih oklepajih. 
s Kanadčanom in angleškemu družinskemu pogovornemu jeziku. Temu nedvomno botrujejo Annina kognitivna izhodišča, ki so se pred začetkom šolanja utemeljila v jeziku njene razširjene družine, jeziku primarne socializacije, intenzivni študij jezikov pa ji je povečal uvid $v$ lingvistične povezave.

Glede na to, da se je Anne leta 1954 rodila v Kanadi, je njena pripadnost tej deželi stalni del njene identitete. Njeno družinsko okolje, ki je določalo tudi njene druge identitetne plasti, pa se ne nanaša le na družino, ki si jo je ustvarila sama, ampak tudi na del v Kanadi živeče primarne družine; močno jo je določala tudi prisotnost tet po obeh straneh. $V$ družinski prizmi se tako poleg kanadske izrisuje dodatni preplet še vsaj dveh kulturnih identitet, slovenske in italijanske, precej šibkeje, zgolj indikativno, pa tudi furlanske (Urbancic 1998: 19). Anninega identificiranja, ki se ob podpori uporabljenih empiričnih virov kaže kot dinamičen intersubjektiven proces, se ne da dobro razumeti brez njene umestitve $v$ kanadsko okolje, brez delovanja $v$ javnem prostoru in brez njenih osebnih premislekov.

\section{PRIMARNA SOCIALIZACIJA: DRUŽINA, ANGLEŠKA ŠOLA, VEČKULTURNA SOSESKA, ITALIJANSKI KULTURNI UTRIP, SLOVENSKA SKUPNOST}

Anne po starših izhaja iz generacije primorskih Slovencev, ki je odraščala v italijanski Julijski krajini. Oče Franc Urbančič (1919-2013) je bil doma iz okolice Pivke, mama pa je bila kot Marija Rustja leta 1923 rojena v okolici Vipave. Čeprav sta oba izšla s slovenskega podeželja, sta se šolala in javno udejstvovala $v$ fašistično zaznamovanem italijanskem duhu. Ta je $v$ dvajsetih in tridesetih letih določal imperative ne le pri rabi jezika, poimenovanju, vrednotah in lojalnosti, ampak je vplival tudi na ekonomske možnosti in uvajanje materialne kulture, tudi prehrane (Urbancic 2014a). Na negativni odnos njenih staršev do političnega razvoja in vklopitve slovenske Primorske $v$ italijansko Julijsko krajino namigne Annin stavek, »bila sta prisiljena (op. a.) postati italijanska državljana«, ki ga lahko razumemo kot družinsko dediščino kolektivnega spomina na dogodke po Véliki vojni.

Oče Franc je Anne večkrat pripovedoval, kako je bil zasmehovan, če je učitelju priznal, da doma, v kmečki družini z osmimi otroki, govorijo slovensko (Urbancic 1998: 24). V tridesetih letih se je izučil za krojača, vojsko pa je služil kot alpin, pripadnik tradicionalne gorske pehote kraljeve vojske. Med vojno je bil vpoklican v notranjost Italije kot član pomožnih vojaških del (t. i. battaglioni speciali). Po kapitulaciji Italije leta 1943 je odšel domov, od junija 1944 do aprila 1945 pa so ga v zaporu Coroneo v Trstu nacisti brez obtožnice vzeli za talca, ga pretepali, stradali in vpeli v prisilno delo. Vrnil se je domov in bil zaradi zadržanosti do komunizma kmalu na piki povojnih jugoslovanskih oblasti. Bil je opozorjen, »naj takoj odide ali pa bo ubit«, zato je brez slovesa od preostalih članov družine s sestro Frančiško zbežal v Italijo. Najprej so ga poslali v begunsko taborišče $v$ Trst, nato $v$ druga begunska taborišča $v$ Italiji, dokler se mu leta 1950 ni ponudila priložnost za odhod v Kanado. 
Annina mati Marija je odraščala na Vipavskem v revni kmečki družini s štirinajstimi otroki. Ko je njena mama ovdovela, je morala kot 16-letno dekle od doma služit kot hišna pomočnica. Najprej je odšla v Trst in nato $v$ Torino, kjer je bila ves čas močno vpeta $v$ italijanski prostor. Poleg italijanskega jezika, ki ga je govorila $z$ delodajalci, se je kot služkinja naučila pripravljati italijansko hrano in se seznanila s kulturo italijanskih (višjih) slojev. Po vojni se iz Torina ni vrnila domov, ampak se je zaposlila v Trstu, od koder je leta 1953 odšla v Kanado, kjer se je v Torontu pridružila sestri Julki.

Annina starša sta se leta 1953 spoznala šele v Torontu. Kmalu sta začela skupno življenje $v$ etnično mešanem predelu mesta s pomenljivim imenom Little Italy, »poseljenem z rojenimi Kanadčani, Kitajci, Grki, Ukrajinci in drugimi«. Zanju je bila italijanska soseska »cona udobja«, glede na to, da primerljivega slovenskega predela v Torontu ni bilo (Urbancic 2014a). V Little Italy je bilo veliko priložnosti za dostop do italijanskega kulturnega utripa in butičnih trgovinic z italijanskimi izdelki, kot denimo macellerie ('mesnice'), pasticcerie ('slaščičarne'), pescherie ('ribarnice'), prodajalne kavnih mlinčkov, posod za pripravo polente ali naprav za izdelavo domačih testenin. To okolje je številne italijanske priseljence in tudi Slovence iz nekdanje Julijske kraji$n e, v$ veliki večini suverene $v$ italijanščini in blizu italijanski kulturi, navdalo $z$ domačnostjo in s samozavestjo - ob siceršnji izgubljenosti v (začetnem) stiku s kanadsko kulturo in $z$ angleškim jezikom.

Medtem ko je Marija tako kot številne ženske $v$ tradicionalnih okoljih po poroki ostala doma, se je Franc v Torontu zaposlil v proizvodnji moških oblek, nato pa je delal kot šolski hišnik. Dolgo je bila del družine tudi očetova sestra Frančiška, kar - kot omenja Anne - pri slovenskih priseljencih ni bil redek pojav. ${ }^{12}$ Ker si sama ni ustvarila družine, je imela teta Frančiška pomembno formativno vlogo pri vzgoji prvorojenke Anne.

Zelo dobro se spominjam, da sem znala brati in pisati preden sem šla v šolo, ker me je naučila moja teta Frančiška. Vendar ne $v$ angleščini. Ko sem šla $v$ šolo, sem prvi dan v šoli imela to prelepo učiteljico s čudovitim obrazom, gospo Melanson, ki je šla do table, nanjo pa narisala krog. Spodaj je napisala: B, A, L, L. Bila sem čisto iz sebe. Ker moja teta me je naučila, da je tisto žoga. Kdo je torej lagal? Moja teta? Ali moja prelepa nova učiteljica angleščine?

V šestdesetih letih, ko je Anne obiskovala šolo, Kanada še ni imela izdelane pedagoške sheme za šoloobvezne priseljenske otroke. Pedagoška priporočila so temeljila na asimilacijskem modelu in so se razlikovala od današnjih kanadskih standardov, ki so

12 Razširjene družine v priseljenstvu pogosto ustvarijo osnovno družinsko celico, ki omogoča učinkovitejšo ekonomsko in socialno opolnomočenost. Večina diasporičnih raziskovanj se glede tega nanaša na afriške, azijske in karibske primere; pri tem se največkrat omenja stare starše, bistveno manj pa horizontalno sorodstvo, torej tete, strice in podobno. Razširjene družine in neposredno skupnost (sosedstvo) Creese navaja kot ključen kontekst, v katerem se vzgaja otroke in izvaja druge družinske odgovornosti (Creese 2011: 152). 
šele $v$ sedemdesetih letih uvajali principe večkulturne in medkulturne pedagogike (Vižintin 2017: 23, 30). Angleški jezik, ki ga je osnovnošolka Anne hitro usvojila, ji je omogočil lažje sledenje šolskemu procesu in druženje z drugimi okoliškimi otroki. Eden od najmočnejših mejnikov v procesu »postajati Kanadčanka i je bila anglifikacija osebnega imena. Glede na spodnjo anekdoto je treba poudariti, da je do simbolne preobrazbe iz Ane v Anne prišlo z njenim pristankom oz. njeno otroško logiko, v kateri je mogoče zaslutiti željo po sprejetosti ter izogibanju izključenosti in morebitnim poniževanjem vrstnikov.

Ker sem bila A-N-A, so me klicali Ana in to kot Ana-Banana. Ker nisem želela biti Ana-Banana, sem praktično takoj postala Anne in učiteljica me je klicala Anne. Rekla bi, da sem imela veliko srečo, ker se številnim imenom, ki danes zvenijo povsem običajno, učitelji tedaj niso posvečali ali jih ohranili. Na primer, poznam žensko po imenu Rachele, ime ima angleško inačico Rachel, ampak njeno ime je bilo spremenjeno v Carol, ker učitelji niso hoteli izgovarjati Rachele. Za tem je stal odnos, zdaj ste v Kanadi, ste Angleži. Dejstvo, da je gospa Melanson napravila le to drobno spremembo iz Ana v Anne, je bila zame velika sprememba. Bila je simbolika druge spremembe, ki se je pojavila, dejstva, da sem prinesla angleščino domov. Angleščina pa je bila seveda jezik višjih struktur in jezik prestiža.

S tem ko je iz šole v svoj dom Anne (in pozneje tudi njeni mlajši sorojenci) prinašala angleške jezikovne in kulturne prakse, je vzpostavila kulturni most, ki je njeni celotni družini povečal možnosti za integracijo $v$ kanadsko okolje. Uspešna umestitev Urbančičevih $v$ neposredno soseščino je pogojevala njihov vzpon z dna skupaj z boljšimi možnostmi zaposlitve. Anne denimo poudarja, da je očetu, ki je zaradi zaprtja tekstilne tovarne izgubil službo, novo delovno mesto v skoraj povsem anglofonskem okolju omogočil sosed. Dobrine, informacije in druge oblike pomoči, kot so zakrožili z vzpostavljenimi družbenimi stiki, so, podobno kot številnim priseljencem, tudi Annini družini do neke mere nadomestili izpad socialne mreže, ki jo v izvorni domovini navadno omogočajo znanci in sorodniki.

Za Urbančičeve je bila zelo pomembna tudi vključitev $v$ slovensko-kanadska združenja, ki so simbolizirala stik z izvornim, domačim, s slovenskim. Anne je poudarila zlasti pomen cerkvenih dejavnosti, tudi občasnih zabav, plesov, dobrodelnih prireditev in drugih dogodkov s slovenskim pečatom. Kot številni drugi starši so tudi Urbančičevi vpisali svoje otroke $v$ slovensko šolo, nastalo pod okriljem cerkvenih avtoritet, $s$ čimer so nameravali ohranjati svojo izvorno tradicijo, predvsem znanje jezika, na svoje potomce. Anne se je rada učila jezika, odbil pa jo je zaničljiv odnos do Primorcev. ${ }^{13}$ 
Ko je vseh nas pet zraslo, smo šli v slovensko šolo, slovenska šola takrat pa je bila skoraj de rigueur. Moral si iti, sicer si bil nihče, pa kljub temu smo bili nihče. (smeh) Spomnim se, da je bilo pravzaprav zelo težko! Spomnim se, da je vsa ta zadeva s Primorci vedno prišla na površje in ne vem, zakaj. Bili so učitelji, ki so se v to res vpičili. Eden od učiteljev nas ni imenoval Primorke, imenoval nas je "prišmrkle«. (smeh) Nisem imela pojma, zakaj in tudi mi ni bilo zares mar. Samo vedela sem, da je bilo nekaj. In čeprav sem bila del zbora, mladinskega zbora, je bil zmeraj takšen občutek, da nisem zares pripadala tja. Posledično sem se držala stran od vseh drugih slovenskih aktivnosti. Nikakor nisem rada šla na Slovensko farmo. Bil je cel boj, da bi [...] in končno so se moji starši vdali in rekli »Ne rabiš več iti.« Nisem se pridružila Marijini legi, Marinski legi ...?

U: Marijina legija.

A: Legija. Tej se nisem pridružila. Nisem šla na nobenega od plesov, na nobeno od zabav ali kaj podobnega. Nisem se pridružila veliki skupini mladih žensk mojih let, ki so stregle na banketih in podobnih zadevah.

Na soroden občutek izrinjenosti, neumestljivosti v slovensko skupnost, ki je temeljil na logiki izključevanja zaradi primorskega izvora s strani slovenskega župnika v Torontu, sem naletela še pri enem pričevalcu (Strle 2009: 145). Posledično odraščajoča Anne v prihodnje ni želela imeti ničesar s slovensko skupnostjo, niti z njeno primorsko vejo. Kljub temu je uspešno končala slovensko šolo in še vedno hrani diplomo, ki jo je izdelal arhitekt, publicist in kulturni delavec tržaškega rodu, Vilko Čekuta (19152014), ki je prišel v Kanado leta 1955. Z zaključnim spričevalom se je za tri desetletja končalo tudi njeno aktivno umeščanje $v$ slovensko skupnost.

\section{GRADNJA PRIPADNOSTI}

In tako se je moj svet začel razraščati na drugačen način, izven slovenske skupnosti. Ker sem študirala in oboževala jezike, je moj svet vase sprejel francosko in italijansko skupnost. Šel je nazaj v italijansko, ker imamo italijanske korenine. Našla sem si svoje poletne službe, nisem prosila slovenske skupnosti, če mi jo najde ali pomaga. [...] Tako sem se res umaknila iz celotne skupnosti, zelo malo sem imela opravka s slovensko skupnostjo. In, presenečenje, nisem se poročila s Slovencem! (smeh)

$\mathrm{U}$ : Ljubezen nima meja.

A: Res je. Pet nas je in nihče se ni poročil s Slovencem ali Slovenko.

Obdobje, ko se je Anne uprla umeščanju v slovensko-kanadska društva, kronološko sovpada s pojavom uporniške generacije, ki je na prehodu v sedemdeseta leta odločno prelamljala s tradicijo. Kljubovala je prisili, utečenim potem, sprejetim normam in se bolj našla v ubiranju novih življenjskih slogov, premislekih o lastnem vrednostnem sistemu, pogosto brez pravih vzorov. Na pomenljivo stališče, ki subtilno izkazuje 
kljubovalnost, Anne postavlja njena izjava: »Moji bratranci so bili vedno ‘bolj krotki kot jazı." Poleg tega je bila Anne prva v družini, ki se je vpisala na univerzo. Tudi to je znamenje preloma, sploh s stališča enega od njenih srednješolskih učiteljev, ki je menil »da dekleta ne potrebujejo izobrazbe« (spletni vir 2). Univerzitetno izobraževanje je obenem okrepilo tudi njeno samorefleksijo, $s$ katero je svojo identiteto oblikovala po lastnih premislekih in brez zakoreninjenosti v tradicijo in rigidne kulturne oprimke (prim. Giddens 1991).

Anne je uspešno doštudirala italijanščino in francoščino ter študij nadaljevala na Oddelku za italijanistiko Univerze $v$ Torontu, »ker je bil tukaj največji in najboljši oddelek za italijanske študije izven Italije (spletni vir 3). Na istem oddelku je zatem veliko let tudi poučevala. Seznanjanje s praktično vsemi vejami humanistike, ambicija in predanost ne le študiju, ampak tudi novim spoznavnim orodjem, so jo oblikovali v italijanistko $z$ izrazito interdisciplinarnimi razgledi. Njen svetovni nazor se je ob poklicnih naporih in razmišljanjih oplajal s kozmopolitskimi prepričanji, ki pa so se, če so bili etnični, bolj navezovali na italijansko kulturo; to so $v$ kanadskem okolju povsem prevzele tudi tete po mamini strani. Ob tem je njena slovenska angažiranost praktično izostala, slovensko pripadnost je izkazovala predvsem $v$ intimnosti doma svojih staršev.

Pomemben mejnik $v$ njenem istovetenju s slovenstvom sega $v$ devetdeseta leta. Verjetno je povečano občutenje slovenstva dozorelo skupaj z dogajanjem na makro ravni. Kanada je namreč $\mathrm{s}$ spodbujanjem multikulturnih praks in $z$ obeleževanjem podob svoje raznolikosti od devetdesetih let ozaveščala širše množice, ${ }^{14}$ obenem pa se je Slovenija kot samostojna država pojavila na svetovnem političnem zemljevidu. Kljub temu ne smemo spregledati Anninega argumenta, da ga je v njej znova prebudila družinska dinamika, zlasti izkušnja materinstva oziroma premišljevanje, kaj iz svoje lastne dediščine lahko posreduje hčerkam.

Moj mož je zelo družinski človek. Je sedma generacija Kanadčanov in je vedel zelo malo o svojih koreninah. Tako je začel malo poizvedovati, in medtem ko so najini otroci rasli, sem se spraševala, kaj pa bodo vedeli o meni. Potica? Saj niti speči ne znam potice! Niti si ne želite, da pečem, ker je vse, kar spečem, polomija. Najbrž sem dobra učiteljica, ampak sem grozna pekovka. (smeh) Ne vem, kako se lotiti tistih stvari, ki jih Vicki Galloway imenuje štirje F-i kulture, saj veš, food ('hrana'), fun ('zabava'), fairs ('sejmi'), festivals ('festivali'). Nikoli se tega nisem udeleževala. Ampak kar sem spoznala, je to, da moram dati [...] Bilo je odvisno od mene, res je bilo odvisno od mene, da dam svojim otrokom, svojim trem hčeram občutek samoidentitete, ki

14 Kanada je multikulturno politiko uradno razglasila leta 1971, leta 1982 sprejela zakonski predlog o multikulturalizmu, šele leta 1988 pa ga je temeljiteje določila v Multikulturnem zakonu. Leta 1991 je sprejela t. i. Broadcasting Act, zakon o telekomunikacijah, ki je usklajen z javno multikulturno politiko, s katero Kanada spodbuja raznovrstnost kanadskih kulturnih izrazov in s tem krepi svoje politične, ekonomske in socialne strukture. (Fleras, Elliott 1992; Kelley, Trebilcock 2000) 
bi vključevala tudi njihove slovenske prednike. Zato ker, ko sta moja starša postala starejša in je njuna angleščina začela izginjati zaradi kognitivne slabitve, jima je v ospredje vedno bolj prihajala slovenščina. In to zelo stara slovenščina, izpred 50, 60 let, ko sta odšla. Ker te sta se spominjala.

Sumarizirana pripoved o prehodu $v$ intenzivno spraševanje o plasteh lastne istovetnosti, ki se je utrnilo $v$ živem stiku med Anninimi predniki in potomkami, zakriva nekaj zanimivih razvojnih vijug. Te izhajajo z obmejnih območij $z$ več etničnimi vplivi, ki določajo ekonomsko, politično, zlasti pa družbeno in kulturno realnost. Anne je o tem začela intenzivno razmišljati v poznih devetdesetih letih. Njen prvi javni zapis iz leta 1998 je v tem smislu še precej svež, iz njega jasno veje vznemirjenost ob premišljanju o identitetnem umeščanju svojih prednikov, preudarnem razbiranju korenin svojih treh hčera, pa tudi o svoji lastni pripadnosti (Urbancic 1998: 19).

Je tudi zgodba, ki se je osebno bojim zapisati iz očitnega razloga - ta zgodba se konča z mano. Ker se temu dejstvu ne da izogniti, čutim potrebo prenesti to zgodbo na moje hčerke, ki so Kanadčanke in se ne mučijo s problemom identitete. [...] Bilo bi obžalovanja vredno, če bi moji otroci pozabili svoje italijansko-slovenske korenine, če nikdar ne bi vedeli, zakaj stari starši rečejo njihovi sestrici stvari kot: Bi šla zdaj ninat? ali Batti batti le manine [otroška pesmica, op. a.]. Zanje so to čudne besede, najbrž brez pomena, vendar so nedvomno povezave, ki razkrivajo njihovo ozadje. So ostanki starih plamenov, kot je rekel Vergil. So pa tudi filamenti, ki krepijo korenine njihove samoidentitete. (Urbancic 1998: 20)

V pričujočem članku se je svoji identiteti posvečala predvsem s stališča jezika in sociokulturne pripadnosti, z raziskovalnih področij, ki jih najbolj pozna. Ob razmišljanju o lastni identiteti jo je fascinirala zgodba sorodnikov po materini strani, ki je - ob slovenskem izvoru in hkratni italijanski socializaciji - izpadla iz enoznačne umestitve $v$ eno etnično strukturo. Namesto izključujoče kompetitivnosti dveh narodnih elementov izkazuje prepletenost elementov italijanske in slovenske kulture (prim. Milharčič Hladnik 2011). Ta perspektiva je lahko polnejše ovrednotena šele, če spustimo raziskovalni fokus na dogajanje od spodaj, preko oblik vsakdanjega življenja in družbenega vibriranja na lokalni ravni, kar pomembno dopolnjuje in občasno tudi izziva državne in nacionalistične perspektive (Rumford 2014: 163). Materina zgodba izkazuje intenzivno fuzijo dveh kultur, ki se zaradi neposredne fizične bližine, kot je smiselno zapisala Anne, »nista mogli ne prezreti niti izogniti druga drugi« (Urbancic 1998: 21).

$\mathrm{V}$ zapisu, kjer interpretira nedvomno zanimive vidike italijansko-slovenske prepletenosti, se očetovi specifični življenjski zgodbi, ki bolj ustreza monolitnim etničnim vatlom, manj posveča; prikaže le izrazito medetnično konfliktnost, ki je prav tako močno določala zapletene odnose na obmejnem pasu. $V$ zgodbi zavednega primorskega Slovenca, podvrženega italijanizaciji, se je Anne v večji meri napajala iz makroperspektiv, ki za slovensko-italijanski obmejni pas še vedno prevladujejo. 
Večinoma so iz politične zgodovine in so se več kot stoletje in pol učinkovito oplajale z izključevalnimi nacionalnimi retorikami in nasiljem, se močno zaostrile z grozotami druge svetovne vojne in povojnega časa, se krepile z geopolitičnimi delitvami hladne vojne, danes pa se obnavljajo $z$ (pogosto potvorjeno) zgodovinsko rekonstrukcijo za politično mobilizacijo volilnega telesa. $V$ očetovi zgodbi se izrisuje zlasti postopni kulturni genocid Italijanov nad Slovenci, ki so ga italijanske oblasti nad slovensko manjšino bolj ali manj odkrito izvajale vse od dvajsetih let 20. stoletja.

Annino razumevanje lastne družinske genealogije, zaznamovane $z$ italijansko-slovenskim nabojem, seveda ni brez podlage. Čeprav bi lahko kdo ugovarjal, da sta oba njena starša izšla iz slovenskega okolja s slovenskimi starši in nista nič drugega kot Slovenca, je Anne njuni zgodbi analitično razumela v razponu celotnega življenja, onkraj nacionalističnih retorik in s premisleki o gradnji njune osebne identitete, umeščene na obmejno območje. Ta pozicija sicer spodbuja rigidno umeščanje v določeno obmejno skupnost, omogoča pa tudi izražanje prelivajoče se lojalnosti (prim. Ballinger 2006: 120). Slednje je pogojeno zlasti z delovnimi in drugimi pragmatičnimi praksami, kot jih nakazuje socializacija Annine matere. Marija Rustja se je šolala v italijanski redovniški šoli v Cormonsu/Krminu, nato pa se, ko je nehala delati kot hišna pomočnica $v$ italijanskih mestih, ni več vrnila domov. Nanjo je močno vplivalo tudi to, da je v Kanado prišla kot italijanska državljanka. Oče se je po vojni sicer vrnil domov na Pivško in pridobil jugoslovansko državljanstvo, je pa tudi njegova preteklost nosila italijanski pečat, utemeljen z italijansko vojaško odpustnico.

Anne majceno skupnost priseljencev, ki so v Kanado vstopili kot (nekdanji) italijanski državljani slovenskih korenin, imenuje Italo-Slovenci. To na prvi vtis nenavadno skovanko prvenstveno uporablja za potrebe raziskave, zanjo je nekakšno analitično sito v presejevanju raznovrstnih priseljenskih skupnosti v Kanadi. Izraz nima natančno definiranih kriterijev, saj ga ob objektivnih vidikih določajo zelo subjektivne izkušnje in osebne izbire. Italo-Slovenci so posebna skupinica v slovensko-kanadski skupnosti, ki je po srcu resda slovenska, vendar je italijanska po spominih (Urbancic 1999: 73). Anne opaža, da v Torontu le še peščica starejših ljudi - bržkone zaradi težavnih osebnih zgodovin - sistematično zavrača pripovedovanje o preteklosti, njihovi potomci pa se razmeroma hitro vklapljajo $v$ kanadsko družbo in puščajo za sabo le obledelo sled svojih prednikov. Največkrat so družbeno aktivni v slovensko-kanadskih skupnostih, v vsakdanjih praksah pa se zrcali neizbrisen italijanski pečat njihove primarne socializacije. Pogovorni jeziki v tej mali skupnosti so svojevrsten preplet slovenščine, italijanščine in angleščine (Urbancic 1999: 76-77).

Naklonjenost do italijanskega kulturnega prostora, $v$ katerega je bila mlada Anne umeščena $v$ Torontu, se je utrjevala $s$ folklorno dediščino matere (kuhinja, nakupovanje, ljudsko izročilo, popularna glasba) in njenih sorodnikov. Ker je obenem med študijem in v poklicu intenzivno spoznavala italijansko kulturo in jezik, je $v$ Anninem občutenju identitete italijanski vidik kar nekaj časa prevladoval nad slovenskim. Njeno vnovično zbliževanje s slovenstvom ni pogojeval le razmislek o svojem slovenskem izvoru in identitetnih nastavkih svojih hčera, ampak tudi gesta 
tedanjega predstavnika skupnosti Vseslovenskega kulturnega odbora, Staneta Kranjca, ki je prepoznal Annine intelektualne in socialne kapacitete ter jo leta 2003 povabil v Canadian-Slovenian Historical Society. Z vabilom se je Anne odprl prostor za oblikovanje pozitivnejšega odnosa do slovensko-kanadske skupnosti in za raziskovanje izvorne kulture svojih prednikov.

Stane Kranjc je govoril z mano o tem in razmišljala sem, da je moja odgovornost, da zagotovim svojim hčeram [...] na nek način sem bila zelo sebična [...] da moje hčere vejo, da obstaja nekaj z imenom Slovenija in da spadajo tudi tja. Da je to del njih, pa če jim je to všeč ali ne. Tako sem se pridružila zgodovinskemu društvu. Začetni namen zgodovinskega društva je bil, mislim, samo zbiranje zgodb [slovensko-kanadske] skupnosti in jih objaviti v knjigi. A spoznala sem, da je to priložnost za nekaj bistveno večjega, za arhive. Udeležila sem se arhivskega tečaja [ki so ga pripravili v Ljubljani]. Opravila sem tudi druge tečaje. Ker nisem arhivistka, sem opravila razne tečaje tu v Kanadi.

V posameznikovem življenjskem ciklusu se lahko identificiranje $z$ določeno etnično pripadnostjo, sploh če izhaja iz dvo- ali večkulturnih okolij in ima migrantsko ozadje, korenito spreminja. Tudi Anne je zlagoma razvila svojo osebnostno samopodobo, ob večji umirjenosti in odgovornosti je $v$ primerjavi z mladostnimi leti pridobila tudi večje razumevanje in notranjo gotovost. To je poudarila $v$ anekdoti o tem, kako je doživela ponovni poskus omalovaževanja v slovensko-kanadski skupnosti.

Trajalo je strašno dolgo, preden so nam ljudje zaupali, nas sprejeli in nam verjeli, da njihovih zgodb ne bomo izrabili in uničili ... [...] Bila sem na predstavitvi našega dela in predstavil me je eden od duhovnikov. Zelo je pomembno, da imaš na svoji strani duhovnike. Bil je zelo naklonjen in zelo podporen, predstavil me je z mojim polnim nazivom Dr. Anne Urbancic z Univerze v Torontu. Ko sem končala z govorom in so me ljudje spraševali, sem slišala neko žensko reči nekomu drugemu: »Ja, ma to je Urbančičeva, ja, a jema kej šule?« (smeh) In sem si mislila, veš, temu nikdar ne bom mogla uiti, vedno bom Urbančičeva, primorska punca, saj veš, temu nikdar ne bom mogla uiti.

U: Prišmrkla ...15

A: Prišmrkla. Tako je. To bom vedno ostala. Ironija je, da ko je rekla, »a jema kej šule« (»ali ima kaj šole«), je tudi to v dialektu, pravzaprav na zelo nizki stopnji, daleč od slovenskih standardov. Morala sem se smejati, takrat sem bila precej starejša in sem se lahko smejala. Hipoma sem pomislila na mlado sebe, $v$ moje misli je prišla tista mala punčka, ki se je počutila tako izobčeno zaradi vseh teh identitet. Ko me torej ljudje zdaj vprašajo, kakšna je tvoja identiteta, še vedno ne vem. Sem Kanadčanka, sem Italijanka, sem Slovenka, sem Primorka, od tega ne morem ubežati, ne? Ampak

15 Kot nakazuje Annin narativni pasus o pouku na slovenski šoli v Torontu, je izraz "prišmrkla« cinična, celo zaničljiva izpeljanka izraza za mlado dekle s primorsko provenienco. 
sem opazila, da sploh ni pomembno, ker sem vse od naštetega, lahko grem v tiste kraje, lahko sem v tistih krajih, lahko sem oseba v krajih, ki jih odseva moja identiteta. In ne počutim se izobčene.

Dejstvo, da nihče od Anninih sorojencev ne čuti potrebe po udeležbi v aktivnostih slovensko-kanadske skupnosti, priča o tem, da je identitetne vezi z izvorom svojih staršev vzpostavila samostojno, po lastnem premisleku in spletu naključnih dogodkov. Še več, s ponovno krepitvijo jih je deloma prenesla tudi na svoje otroke, ki se zavedajo, da v krajih, v kateri so odraščali Annini predniki, obstajata posebna kultura - in poseben jezik.

Tako sem ponosna, da imajo tudi brez znanja jezika občutek, kaj pomeni »to je moj ata«, kličejo ga »ata«, in »to je moja nonni«. Torej ona ni stara mama, ona je nonni, kar je po italijansko.

U: No, tudi primorsko.

A: Ja, res je. In imamo teto in tete. In moja teta, ki je živela z nami, ker je bila odlična teta [...] dekleta niso vedela, kako naj jo kličejo, pa so jo imenovale tetateta, ker je bila dvakratno teta (smeh). Nje sicer ni več, ampak vsakdo je vedel, kdo je »tetateta«, »ata« in »nonni«. Res imajo veliko ljubezen in spoštovanje do mojih staršev. Nikoli se niso smejale ali nasmihale, ko je moj oče, ki je pri 93 letih kognitivno oslabel, preskočil v slovenščino. Samo poslušale so ga, rekle »ja« ali "yes« ali »oh, ata, to moraš razložiti v angleščini!« In je rekel: "Saj vem, saj vem, saj ne govoriš slovensko.« In vedno me je pobaral: »lih učiš slovensko?«

\section{ZA KONEC}

Kot kaže pričujoči biografski očrt, ki se napaja iz različnih virov, nastalih v dvajsetih letih, Annino etnično istovetenje izkazuje časovno pogojeno spremenljivost. Vendar tudi iz intervjuja, torej iz časovno enkratne naracije, izhajajo identitetne perspektive $z$ ambivalentnimi razlagalnimi možnostmi. Ko Anne razlaga o identitetnih izvorih svojih staršev, se njeno premišljevanje v glavnem veže na kolektivni spomin primorskih Slovencev $v$ času fašizma, nekoliko skromneje pa tudi na odnos povojnih jugoslovanskih oblasti, ki je bil med številnimi drugimi razlog za prebeg njenega očeta, zavednega Slovenca in katolika. Ko pa pripoveduje o vsakdanjih praksah svoje mame (priprava hrane, poslušanje glasbe, petje pesmi, nakupovalne navade), so spominjani kulturni kodi v etničnem smislu že bolj izmuzljivi. Anne med drugim poudarja, da je bila mamina domača kuhinja $v$ Torontu hibridna mešanica italijanske (mediteranske) in slovenske (srednjeevropske) kuhinje, obenem pa hibridnost navaja kot običajen odraz kulinaričnih praks med t. i. Italo-Slovenci v Torontu (Urbancic 2014a). $V$ teh sklepnih ugotovitvah se kristalizira velik pomen materine (ženske) perspektive, ki v premislek o identiteti omogoča vključevanje vsakdanjega življenja 
in s tem posreduje bistveno manj spolitizirano in etnocentrično identitetno podobo primorskih Slovencev, kot izhaja zgolj iz očetove zgodbe. Materina perspektiva nudi tudi bolj argumentirane nastavke za razlago tega, zakaj je Anne, hči primorskih Slovencev, tako močno prevzela italijansko identiteto.

$V$ rekonstrukcijah lastne pripadnosti, ki so ves čas potekale $z$ močnim pečatom identificiranja $z$ družinskimi predniki, Anne razkriva ambivalentne identitetne poteze izvornega, obmejnega prostora svojih staršev. Ker je obenem hči priseljencev $v$ Kanado, se je $v$ specifično kulturno umeščenost njenih staršev in $v$ Kanadi živečih tet vrinila tudi priseljenska zgodba, ki je na Annino spreminjajoče se istovetenje vplivala s preigravanjem elementov zgodovine, kultur in vzvodov moči (Hall 1990: 225). Annin primer empirično utemeljuje situacijsko (občutek ne/sprejetosti, intelektualni interesi) in relacijsko (umeščenost $v$ različne kolektivne prostore in njihove kontekste) doživljanje kulturnih vidikov lastne, izrazito večplastne identitete. Kaže tudi, kako se identiteta potomcev priseljencev včasih vzpostavi neodvisno od dozdevno nespremenljivih ali objektivnih dejavnikov (slovenski izvor staršev) in prevzema tudi iz okolja posameznikove socializacije oz. delovanja pred preselitvijo (šolanje staršev $v$ italijanskih šolah, očetovo služenje vojaškega roka v italijanski kraljevi vojski, materina pridobitna dejavnost med italijanskimi delodajalci) in tudi po njej (sledenje italijanskim kulturnim kodom v Kanadi živečih tet po mamini strani). Iz njenega primera izhaja tudi to, da se identificiranje vzpostavlja hkrati s spominjanjem preteklosti, ki je vsakič znova nabito $z$ dinamičnimi prvinami zdajšnjosti (Assmann 2001).

V »identitetnih filamentih «, ki slovenstvo povezujejo $z$ intimnimi, javnosti skoraj nevidnimi oblikami, se v Anninem primeru razgalja emocionalni naboj, ki se je najmočneje utrdil v družinskem kontekstu. Najverjetneje bo ta naboj sčasoma oslabel, ker bodo slabeli tudi spomini in prakse, s katerimi se ohranja zgodovina Annine družine, in se zlili, preoblikovali s kanadskim ali katerim drugim vsakdanom. Annine hčerke po gornjem citatu poznajo le nekaj slovenskih besed, nekaj osnovnih pogovornih izrazov, poimenovanja konkretnih družinskih članov. Ker je bila tako kuhinja Annine matere kot nje same bolj italijanska kot slovenska, poznajo le peščico slovenskih jedi. A vendar, ko je Anne z delom svoje družine leta 2007 obiskala Slovenijo, to zanje ni bil običajen turistični obisk, ampak obisk družinskih lieux de mémoire in prostor, kjer so zaznale pripadnost, povezano s slovenskimi plastmi njihovih osebnih identitet.

Obožujem Kobarid. Muzej v Kobaridu priporočam vsakomur. Mislim, da je prelep muzej, najbolj senzibilen muzej, kar si ga lahko zamisliš. Vprašala sem za karte $v$ slovenščini. [Po našem obisku] nas je uslužbenka slišala govoriti [...] kam bi šle na kosilo, ker smo bile na poti v Avstrijo [...] Prekinila nas je in nam povedala za to odlično restavracijo $v$ bližini in vem, da je bilo to zaradi [moje rabe] slovenščine. Zato ker smo poskusile komunicirati [v njenem jeziku]. In nenadoma smo pripadale. $\mathrm{V}$ Sloveniji me jezik zaznamuje, a le do neke mere. Ljudje razumejo, da sem prišla od drugod, ampak da je neka [povezava] [...] da pripadam tudi jaz. 


\section{LITERATURA}

Assmann, Aleida (2001). Vier Formen von Gedächtnis von individuellen zu kulturellen Konstruktionen der Vergangenheit. Wirtschaft \& Wissenschaft 9/4, 34-45.

Ballinger, Pamela (2006). Opting for Identity. The Politics of International Refugee Relief in Venezia Giulia (1948-1952). Acta Histriae 14/1, 115-136.

Creese, Gillian Laura (2011). The New African Diaspora in Vancouver: Migration, Exclusion, and Belonging. University of Toronto Press, https://doi. org/10.3138/9781442695184.

Febvre, Lucien (2015). Kako rekonstruirati afektirano življenje nekoč? Boj za zgodovino in civilizacija: Beseda in ideja. Ljubljana: Studia Humanitatis.

Fleras, Augie, Elliott, Jean Loenard (1992). Engaging Diversity: Multiculturalism in Canada. Toronto: Nelson.

Giddens, Anthony (1991). Modernity and Self-Identity: Self and Society in the Late Modern Age. Cambridge: Polity Press.

Hall, Stuart (1990). Cultural Identity and Diaspora. Identity: Community, Culture, Difference (ur. Jonathan Rutherford). London: Lawrence \& Wishart, 222-237.

Kelley, Ninette, Trebilcock, Michael (2000). The Making of the Mosaic: A History of Canadian Immigration Policy. University of Toronto Press.

Milharčič Hladnik, Mirjam (ur.) (2011). IN - IN: Življenjske zgodbe o sestavljenih identitetah. Ljubljana: Založba ZRC, https://doi.org/10.3986/9789612542658.

Rumford, Chris (2014). Towards a Multiperspectival Study of Borders. Critical Border Studies: Broadening and Deepening the 'Lines in the Sand' (ur. Noel Parker, Nick Vaughan Williams). New York: Routledge, 161-176, https://doi. org/10.1080/14650040903081297.

Passerini, Luisa (2008). Ustna zgodovina, spol in utopija: Izbrani spisi. Ljubljana: Studia humanitatis.

Portelli, Alessandro (1991). The Death of Luigi Trastulli and Other Stories: Form and Meaning in Oral History. Albany: State University of New York Press.

Strle, Urška (2009). Slovenci v Kanadi: Izseljevanje skozi prizmo življenjskih zgodb. Doktorska disertacija. Ljubljana: Filozofska fakulteta Univerze v Ljubljani.

Urbancic, Anne (1998). The Italo-Slovenes and the Friulians. An Italian Region in Canada: The Case of Friuli Venezia Giulia (ur. Konrad Eisenbichler). Toronto: Multicultural Society of Ontario, 19-32.

Urbancic, Anne (1999). "Italo-Slovenian Immigrants in Toronto: Doubled Ethnicities." A Monument for Italian Canadians (ur. Gabriele Scardellato, Manuela Scarci). Toronto: York University.

Urbancic, Anne (2002). "Memory in The Girl in Black." The Girl in Black (ur. Angela Bianchini). Welland, ON: CSIS, Biblioteca di Quaderni d'Italianistica, 15-27, https:// www.vic.utoronto.ca/about-victoria/victoria-college-fellows-and-associates/ urbancic/ 
Urbancic, Anne (2014a). Place Settings: Food and Identity among the Italo-Slovenians of Toronto: A Revised and Expanded Version of her Presentation at the Perugia Food Studies Conference, Umbra Institute in Perugia, 5-8 June 2014, http:// library2.utm.utoronto.ca/italianopentext/content/session-21-place-settingsfood-and-identity-among-italo-slovenians-toronto (27. 6. 2020).

Urbancic, Anne (2014b). Reviewing Mario Pratesi: The Critical Press and its Influence. Toronto, Buffalo, London: University of Toronto Press.

Urbancic, Anne (2017). Literary Titans Revisited: The Earle Toppings Interviews with CanLit Poets and Writers of the Sixties. Toronto: Dundurn Group.

Vižintin, Marijanca Ajša (2017). Medkulturna vzgoja in izobraževanje. Ljubljana: Založba ZRC.

\section{SPLETNI VIRI}

Spletni vir 1: https://thevarsity.ca/2020/01/31/lessons-in-living-professor-anneurbancic-vic-one/ (30. 4. 2020).

Spletni vir 2: https://thevarsity.ca/2020/01/31/lessons-in-living-professor-anneurbancic-vic-one/ (21. 5. 2020).

Spletni vir 3: https://thestrand.ca/professor-profiles-an-interview-with-anneurbancic-of-victoria-college/ (21. 5. 2020). 


\section{SUMMARY}

\section{IDENTITY TRANSFORMATIONS IN MIGRATORY PROCESSES: THE FLUID BELONGING OF A CANADIAN WITH SLOVENIAN-ITALIAN ROOTS Urška STRLE}

The article is a biographical attempt to explain the fluidity of Anne Urbancic's ethnic identification. She is a daughter of Slovenian parents, who originated in the Julian March and immigrated post-war to Canada. Anne considers herself Canadian, Italian, Slovenian, and Slovenian Littoral, yet over time she has changed the intensity of these identifiers. The reconstruction of Anne's story is based on various sources, including a life-story interview conducted by the author in 2012 and Anne's own scientific attempts to understand her multilayered identification process. When Anne analyzes the identity of her parents, her remembering is mainly related to the collective memory of the Littoral Slovenians during fascism, and somewhat modestly to the memory of the post-war Yugoslav authorities who stimulated the flight of her father, a politically aware Slovenian and Catholic. However, when she talks about her mother's daily practices (preparing food, listening to music, singing songs, shopping habits), the mentioned cultural codes are already more elusive in an ethnic sense, exhibiting both Slovenian and Italian features. The article also points to the great importance of the mother's (woman's) perspective, which enables the inclusion of everyday life in the reflection on identity and thus conveys a significantly less politicized and ethnocentric identity of Littoral Slovenians than would appear from the father's story alone. The mother's perspective also offers more convincing arguments to explain why Anne, the daughter of Littoral Slovenians, so strongly took on the Italian identity. 